\title{
Chemical Composition and Antibacterial Activity of the Essential Oils from Different Parts of Eugenia caryophylata, Thunb Grown in Amboina Island
}

\author{
Hanoch Julianus Sohilait ${ }^{*}$, Healthy Kainama ${ }^{2}$, Maria Nindatu ${ }^{3}$ \\ ${ }^{1}$ Departement of Chemistry, Faculty of Mathematic and Natural Science, Pattimura University, Ambon, Indonesia \\ ${ }^{2}$ Departement of Chemistry Education, Faculty of Training and Education, Pattimura University, Ambon, Indonesia \\ ${ }^{3}$ Departement of Biology, Faculty of Mathematic and Natural Science, Pattimura University, Ambon, Indonesia \\ Email: *nokesohilait@yahoo.com
}

How to cite this paper: Sohilait, H.J., Kainama, H. and Nindatu, M. (2018) Chemical Composition and Antibacterial Activity of the Essential Oils from Different Parts of Eugenia caryophylata, Thunb Grown in Amboina Island. International Journal of Organic Chemistry, 8, 229-239.

https://doi.org/10.4236/ijoc.2018.82017

Received: April 19, 2018

Accepted: June 17, 2018

Published: June 20, 2018

Copyright $\odot 2018$ by authors and Scientific Research Publishing Inc. This work is licensed under the Creative Commons Attribution International License (CC BY 4.0).

http://creativecommons.org/licenses/by/4.0/

\begin{abstract}
This study aims to investigate the antibacterial activities of essential oils isolated from various parts (buds, leaves and stems) of Eugenia caryophylata. The essentials oils were distillated by steam distillation, and the isolated was analyzed by GC and GC-MS. Five components of each sample of oils (buds, leaves and stems) were identified. Main component in the bud are eugenol (75.30\%), eugenyl acetate (20.93\%) and $\beta$-caryophyllene (3.00\%) and eugenol (82.97\%), $\beta$-caryophyllene (12.84\%) in leaf oil, while in stem oil eugenol (97.75\%). The oils were tested for in vitro antimicrobial activities against Gram-positive bacteria (Staphylococcus aureus and Bacillus subtilis), the Gram-negative bacteria (Escherichia coli and Salmonella typhimurium). The essential oils of bud, leaf and stem oil show that antibacterial activity against Gram-positive and Gram-negative bacteria.
\end{abstract}

\section{Keywords}

Eugenia caryophylata, Essential Oils, Chemical Composition, Antibacterial

\section{Introduction}

Clove (Eugenia caryophylata $=$ Syzygium aromaticum $)$ is one of the most important herbs in traditional medicine. It is locally known as cengkeh and grows naturally in Moluccas Islands, People in Moluccas usually use cloves in cooking, either the whole part or in ground form. This spice is also used for cigarettes known as kreteks [1] in Indonesia, Asia, and Europe. Beside cloves, people also 
use its essential oils for medical purpose, since it active against oral associated bacteria and fungi [2]. Previous studies have reported the antifungal [3] [4] [5], antioxidant [6] [7] [8], antibacterial [9] [10] [11] and anti-inflammatory [12] [13] properties of clove oil. The main component of clove oil, eugenol, has been used as an anti-cancer [14] [15] and as a starting material for synthesis analog L- $\alpha$-metil DOPA [16]. Studies of clove essential oil from different parts of the world showed that the major components of the clove oil usually include eugenol, $\beta$-caryophyllene, $\alpha$-humulene, caryophyllene oxide and eugenyl acetate respectively, and vary in concentration [17] [18] [19] The studies reveal a great variability in chemical compositions of the clove essential oils. Eighteen components were identified in essential oil from Turkey clove bud, where major components are eugenol (87\%), eugenyl acetate $(8.01 \%)$ and $\beta$-caryophyllene (3.56\%) [1]. There are ten components in clove essential oil, with the main components are eugenol (77.81\%), eugenyl acetate (21.30\%) and $\beta$-caryophyllene (8.44\%) [20]. Thirty-eight components were identified in the clove leaf oil from Bangladesh, and the main components are eugenol (74.30\%), eucalyptol (5.80\%), $\alpha$-cadinol $(2.43 \%)$. Thirty one components in bud oil were identified and the main components are eugenol (47.70\%), $\beta$-caryophyllene (18.90\%), benzdene-1-ethyl-3nitro (11.10\%) and benzoic acid 3-(1-methylethyl) (8.90\%) [17]. Studies on the bud and leaf essential oil of clove from India and Madagascar were found 28 and 35 components respectively from the bud oils and the leaf oil from Madagascar is 22 components. Major components in the bud oil from India are eugenol (70\%) followed by $\beta$-caryophyllene (19.5\%) and eugenyl acetate $(2.1 \%)$. A comparison of components of bud and leaf oils from Madagascar is $82.6 \%$ : $82.0 \%$ for eugenol, $7.2 \%$ : $13.0 \%$ for $\beta$-caryophyllene, and 6.0\%: $0.4 \%$ for eugenyl acetate [18]. It has been shown that there are 10 components of bud, leaf and stem essential oils of cloves from Madagascar, Indonesia and Zanzibar. Major components in the bud essential oil from Madagascar and Indonesia are eugenol $(72.08 \%-80.31 \%$ and $77.32 \%-82.36 \%), \beta$-caryophyllene $(2.36 \%-6.38 \%$ and $5.34 \%-8.64 \%)$ and eugenyl acetate $(11.68 \%-21.32 \%$ and $8.61 \%-10.55 \%)$. Major components in the leaf essential oil from Madagascar and Indonesia are eugenol $(80.87 \%$ - 83.35\% vs $75.04 \%$ - 77.54\%), $\beta$-caryophyllene $(11.65 \%-15.02 \%$ vs $17.04 \%-19.53 \%)$ and eugenyl acetate $(0.29 \%-1.45 \%$ vs $0 \%-0.06 \%)$. Major component oil of Madagascar, Indonesia and Zanzibar stem essential oils are eugenol (91.81\% - 96.65\%, 88.76\% - 89.28\% and 87.52\% - 89.47\%), $\beta$-caryophyllene $(1.66 \%-4.48 \%, 7.40 \%-7.75 \%$ and $7.19 \%-9.70 \%)$, [19]. The essential oils of clove from Amboina Island have been reported [21]. As far as we know, this is the first report of the anti-bacterial activity of this clove oil from Amboina Island.

\section{Experimental}

\subsection{Materials}

Buds, leaves and stems of clove plant were collected from Ureng Village, Amboina Island, Moluccas and treated as the raw materials. The raw materials were 
dried under the sun for six until seven days.

\subsection{Essential Oil Isolation from Buds, Leaves and Stems}

The dried plant materials $(1.0 \mathrm{~kg})$ of buds, leaves $(1.0 \mathrm{~kg})$ and stems $(600 \mathrm{~g})$ were treated by steam-distillation method by conventional steam distiller, for 6 hours. The essential oil samples were dried by anhydrous sodium sulfate $\left(\mathrm{Na}_{2} \mathrm{SO}_{4}\right)$ and stored in cool until further analysis conducted.

\subsection{Gas Chromatographs (GC)}

GC analysis of clove essential oil was performed on a Shimadzu QP-2010, equipped with a FID and Rtx-5MS using a fused silica capillary column $(30 \mathrm{~m} \times$ $0.25 \mathrm{~mm}$ ID, film thickness $1.0 \mu \mathrm{m}$ ). Oven temperature was from $80^{\circ} \mathrm{C}$ for 5 minutes and programmed heating from $80^{\circ} \mathrm{C}$ to $280^{\circ} \mathrm{C}$ at a rate of $16^{\circ} \mathrm{C}$ for 6 minutes, and injector temperature $270^{\circ} \mathrm{C}$; detector temperature $280^{\circ} \mathrm{C}$; pressure of carrier nitrogen gas at inlet $7 \mathrm{psi}$, split ratio 40 and volume was $0.5 \mu \mathrm{L}$.

\subsection{Gas Chromatography-Mass Spectrometry (GC-MS)}

GC-MS analyses of clove essential oil were performed using Shimadzu QP-2010 Plus at $70 \mathrm{eV}$ and $320^{\circ} \mathrm{C}$ with auto sampler, system equipped with Rtx-5MS fused silica capillary column $(30 \mathrm{~m} \times 0.25 \mathrm{~mm}$ ID, film thickness $1.0 \mu \mathrm{m})$. Oven temperature was from $70^{\circ} \mathrm{C}$ for 5 minutes, than programmed heating from $70^{\circ} \mathrm{C}$ to $220^{\circ} \mathrm{C}$ at a rate of $10^{\circ} \mathrm{C}$ for 6 minutes, and from $280^{\circ} \mathrm{C}$ for $5 \mathrm{~min}$, injector temperature $270^{\circ} \mathrm{C} .100 \%$ pure helium gas was used as a carrier gas at the con-

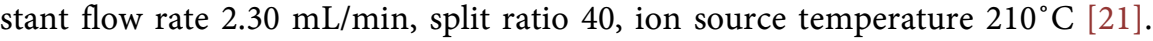
The spectrum of the unknown component was compared with the spectrum of known components stored in the Wiley 7 library. Name, molecular weight and structure of the component of the test materials were ascertained.

\subsection{Antibacterial Assay}

1) Bacterial strains and media

Four strains of bacteria use to assess the antibacterial properties is two Gram positive (Bacillus subtilis FNCC0060 and Staphylococcus aureus ATCC6538) and two Gram negative bacteria (Escherichia coli FNCC0091 and Salmonella typhimurium FNCC0157). All bacteria were grown on nutrient agar (Oxoid).

2) Disc diffusion test

Diameter of zone of inhibition was determined using the disc diffusion method as previously described by Lai et al., 2010 [22] with minor modification. It was performed using a $24 \mathrm{~h}$ culture at $37^{\circ} \mathrm{C}$ in $10 \mathrm{ml}$ of nutrient broth (Oxoid). The cultures were adjusted to approximately $10^{8} \mathrm{CFU} / \mathrm{ml}$ with sterile saline solution based on a McFarland turbidity standard of 0.5. Three hundred microliters of the suspensions were spread over the plates containing Mueller-Hinton agar (Merck) using a sterile cotton swab in order to get a uniform microbial growth on both control and test plates. The essential oils were dissolved in aqueous di- 
methylsulfoxide (Merck) with Tween 80 (0.5\% v/v for easy diffusion). Under aseptic conditions, empty sterilized discs (Whatman, $6 \mathrm{~mm}$ diameter) were impregnated with $20 \mu \mathrm{L}$ of different concentrations $(1: 1,1: 5,1: 10,1: 20)$ of the respective essential oils on the agar surface. Paper disc moistened with aqueous DMSO was placed on the seeded petri plate as a negative control. A standard disc containing ampicilin $(50 \mu \mathrm{g} / \mathrm{mL})$ was used as positive control. All petridishes were sealed with sterile laboratory parafilm to avoid eventual evaporation of the test samples. The plates were left for $30 \mathrm{~min}$ at room temperature to allow the diffusion of oil, and then they were incubated at $37^{\circ} \mathrm{C}$ for $24 \mathrm{~h}$. Antimicrobial activity was indicated by the presence of clear inhibition zones around the discs. Studies were performed in triplicate, and mean value was calculated.

\section{3) Determination of minimum inhibitory and bactericidal concentrations}

The essential oils, which exhibited the best antimicrobial activity in the paper disk diffusion assay, and some individual constituents, were selected for determining the minimum inhibitory concentration (MIC) and the minimum bactericidal concentration (MBC) using broth dilution method (Mith et al. 2014), [23] with minor modification. One colony of each bacterial strain was sampled with a loop, then inoculated in $20 \mathrm{~mL}$ Nutrient broth (NB, Oxoid) and incubated for 18 - $24 \mathrm{~h}$ at $37^{\circ} \mathrm{C}$. The bacterial concentration in the inoculum was standardized at 0.5 on the McFarland turbidity scale, equivalent to $10^{8} \mathrm{cfu} / \mathrm{mL}$. An aliquot $(1 \mathrm{~mL})$ of this suspension was transferred to a sterile tube and the volume was adjusted to $10 \mathrm{~mL}$ with sodium chloride solution $(0.8 \%, \mathrm{w} / \mathrm{v})$ to obtain a concentration of $10^{7} \mathrm{cfu} / \mathrm{mL}$. Working inoculums were prepared by transferring $200 \mu \mathrm{L}$ aliquots of this suspension to three test tubes and adjusting the volumes to $10 \mathrm{~mL}$ with NB medium to give final concentrations of $2 \times 10^{5} \mathrm{cfu} / \mathrm{mL}$. Each essential oil $(500 \mu \mathrm{L})$ was dissolved in dimethyl sulfoxide $(100 \mu \mathrm{L})$ and the volume was made to $5 \mathrm{~mL}$ with sterile $\mathrm{NB}$ containing $1 \%$ Tween 80 to provide a stock solution containing $100 \mu \mathrm{L} / \mathrm{mL}$ of oil. Serial dilutions of each essential oil stock were made with NB to yield final concentrations ranging from $100 ; 50 ; 25 ; 10 ; 5 ; 2.5 ; 1$ and $0.5 \mu \mathrm{L} / \mathrm{mL}$ and mixed with bacterial suspensions with a final concentration of bacteria approximately $5 \times 10^{4} \mathrm{cfu} / \mathrm{mL}$. Final solutions were incubated for 24 $\mathrm{h}$ at $37^{\circ} \mathrm{C}$ in microplate well sterile. The MIC was considered as the lowest concentration that prevented the visible growth and spectrophotometer set at 595 $\mathrm{nm}$. The MBC was determined by subculturing $100 \mu \mathrm{L}$ from each negative test tube onto plate count agar (PCA) plates. MBC was defined as the lowest concentration resulting in a negative subculture or giving presence of only one colony after incubation. The experiments were carried out in three replicates.

\subsection{Statistical Analysis}

The means were analysed by one way analysis of variance (ANOVA) followed by Tukey's post hoc multiple comparison test using SPSS software package version 17.0 for windows. The results were expressed as mean $\pm \mathrm{SD}$. P values $<0.05$ were considered as significant. 


\section{Results and Discussion}

\subsection{Performance of Bud, Leaf and Stem Essential Oil of Clove}

The clove essential oils of buds, leaves and stems were distilled from dried plant material on equipment of the steam distillation. Average yields essential oils isolate in different part of clove were calculated toward the dried materials. The results of clove oil from buds, leaves, and stems were 6.85\% (w/w), 3.21\%, (w/w) and $2.58 \%(\mathrm{w} / \mathrm{w})$, respectively.

\subsection{Chemical Composition of Bud, Leaf and Stem Clove Essential Oils}

GC and GC-MS were use to analyze the clove essential oils from buds, leaves and stems. Five components were identified and quantified, as shown in Table 1, according to their elution order on the Rtx-5 column. The major components of bud are eugenol (75.30\%) and eugenyl acetate (20.93\%). The major component of leaf are eugenol (82.97\%), $\beta$-caryophylene (12.84\%). The major component of stem oil is eugenol (97.75\%). Three major components were observed by GC-MS analysis for ion chromatogram in bud, leaf and stem clove oils. In comparison to standard library data, the peak at $\mathrm{m} / \mathrm{z} 164\left(\mathrm{M}^{+}\right), \mathrm{C}_{10} \mathrm{H}_{12} \mathrm{O}_{2}$, was identified as eugenol, the peak at $\mathrm{m} / \mathrm{z} 204\left(\mathrm{M}^{+}\right), \mathrm{C}_{15} \mathrm{H}_{24}$, was identified as $\beta$-caryophylene and the peak at $\mathrm{m} / \mathrm{z} 206\left(\mathrm{M}^{+}\right), \mathrm{C}_{12} \mathrm{H}_{14} \mathrm{O}_{3}$, was identified as eugenyl acetate. The are two minor components in the mass spectrum, the peak at $\mathrm{m} / \mathrm{z} 204\left(\mathrm{M}^{+}\right), \mathrm{C}_{15} \mathrm{H}_{24}$, was identified as humulene and the peak at $\mathrm{m} / \mathrm{z} 220\left(\mathrm{M}^{+}\right) \mathrm{C}_{15} \mathrm{H}_{24} \mathrm{O}$, was identified as caryophylene oxide. The spectral data matched that given in previous report [21].

Based on this result, it can be inferred that oil from stem contain higher eugenol content than bud and leaf oil, but lower $\beta$-caryophylene and eugenyl acetate content than on bud and leaf oil. Moreover oil from leaf contains higher $\beta$-caryophylene content than bud and stem, and oil from bud contain higher in eugenyl acetate content than oil from leaf and stem.

A typical gas chromatogram of clove oil is shown in Figure 1 (oil from bud), Figure 2 (oil from leaf) and Figure 3 (oil from stem). The MS spectrum of clove oil shown in Figure 4.

The function of secondary metabolite in plant as protectant, attractant and repellent. The repelent in flower dependsvariable factor like phytochemical [24].

Table 1. Chemical composition of bud, leaf and stem clove essential oils.

\begin{tabular}{cccccc}
\hline Compound Name & M.W & Formula & Bud (\%) & Leaf (\%) & Stem (\%) \\
\hline Eugenol & 164 & $\mathrm{C}_{10} \mathrm{H}_{12} \mathrm{O}_{2}$ & 75.30 & 82.97 & 97.75 \\
$\beta$-caryophylene & 204 & $\mathrm{C}_{15} \mathrm{H}_{24}$ & 3.00 & 12.84 & 0.90 \\
Humulene & 204 & $\mathrm{C}_{15} \mathrm{H}_{24}$ & 0.37 & 1.67 & - \\
Eugenyl acetate & 206 & $\mathrm{C}_{12} \mathrm{H}_{14} \mathrm{O}_{3}$ & 20.93 & - & 0.76 \\
Caryophylene oxide & 220 & $\mathrm{C}_{15} \mathrm{H}_{24} \mathrm{O}$ & 0.40 & 2.52 & 0.59 \\
\hline
\end{tabular}




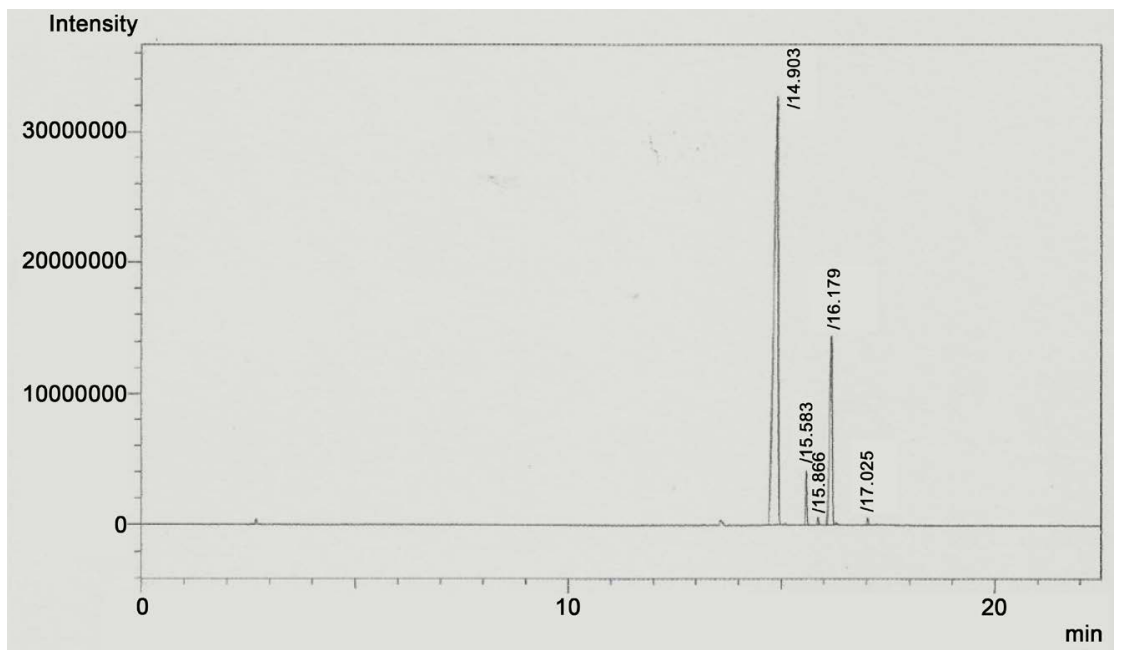

Figure 1. A typical gas chromatogram of the bud essential oil.

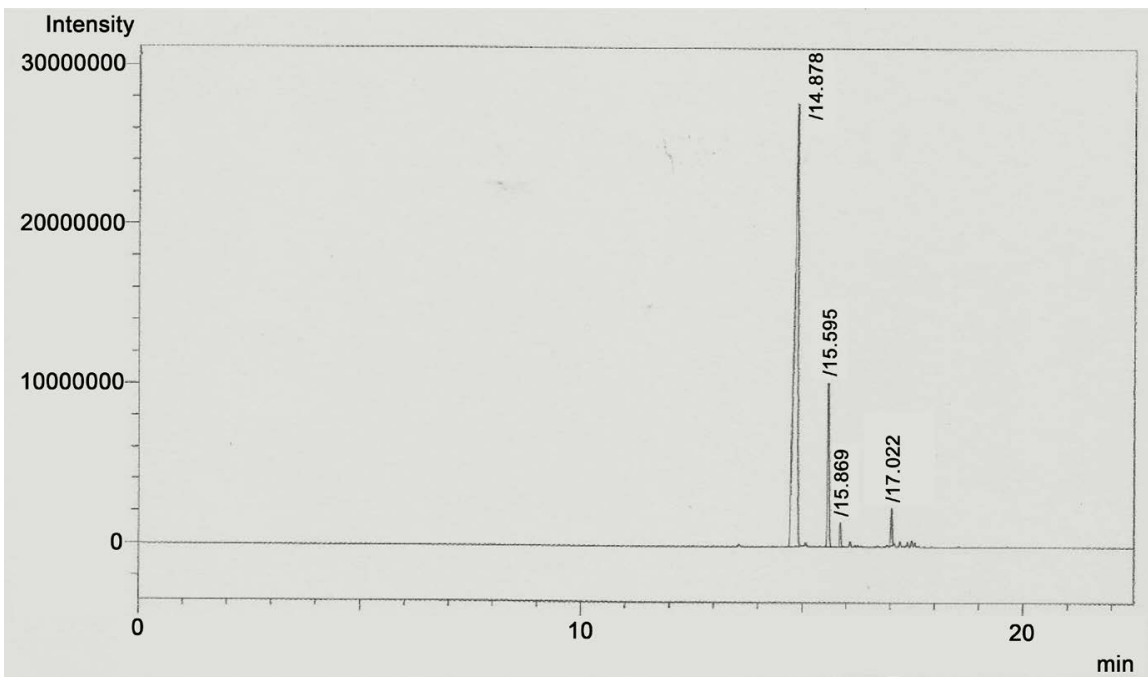

Figure 2. A typical gas chromatogram of leaf the essential oil.

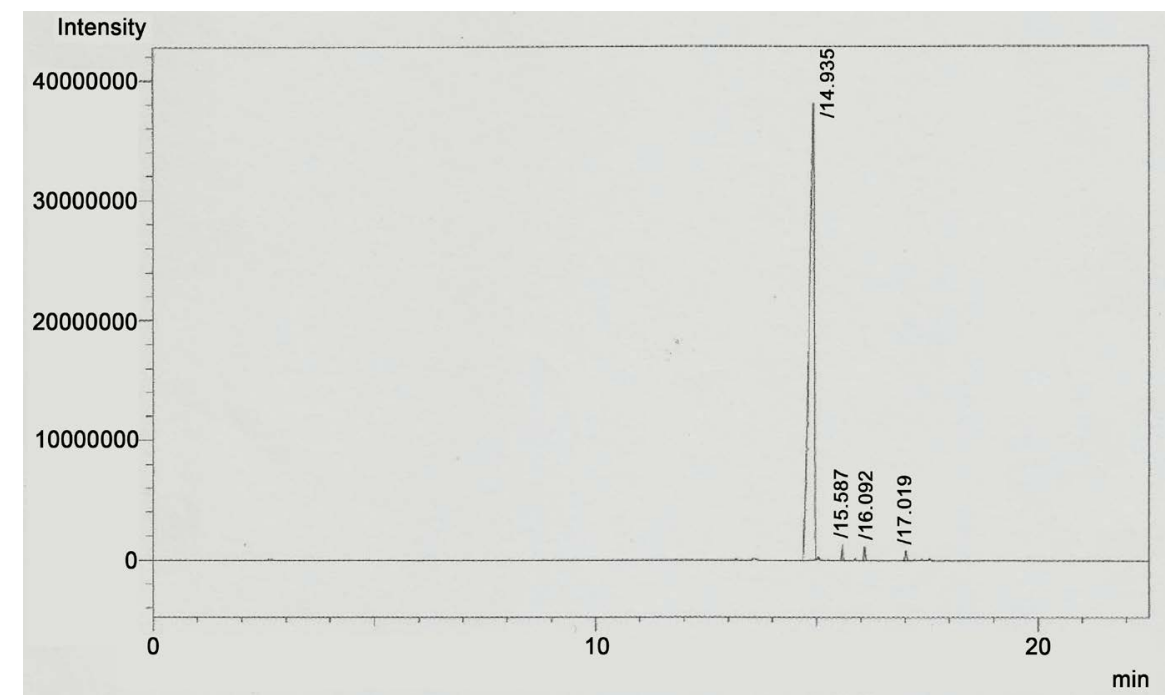

Figure 3. A typical gas chromatogram of the stem essential oil. 

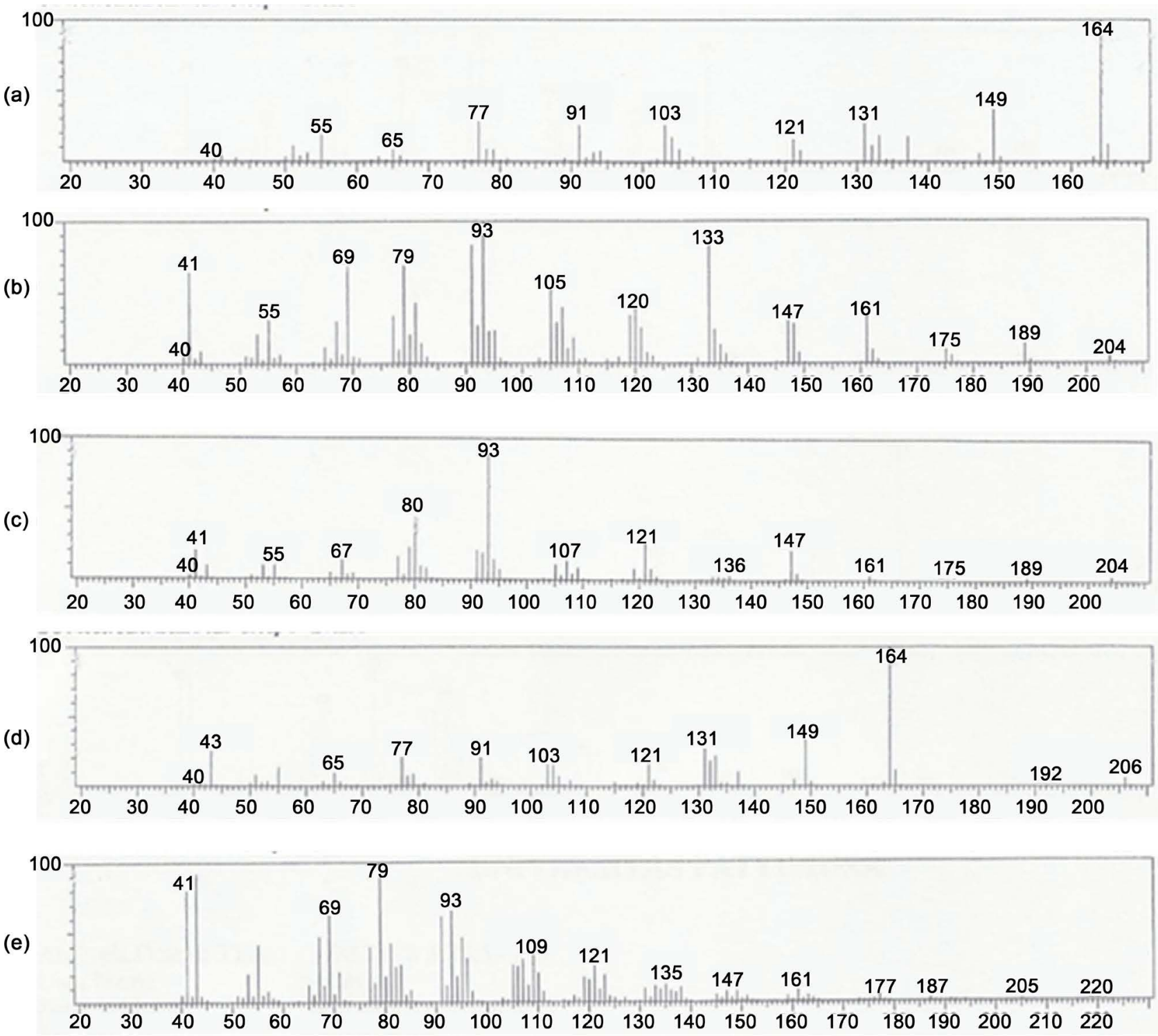

Figure 4. MS Specturm of clove essential oil, (a) Eugenol, (b) $\beta$-caryophylene, (c) Humulene, (d) Eugenyl acetate, (e) Caryophylene oxide.

In the recent study bud contain compounds more than leaf and stem so that more production of compounds.

\subsection{Antibacterial Activity of the Oils}

The antibacterial activity of oil from stem, leaf and bud clove against four strain pathogen bacterial is summarized in Tables 2-4. The stem and leaf clove oils with inhibition zone of $15.05 \pm 0.200$ and $13.5 \pm 0.322 \mathrm{~mm}$, respectively, were found to be more active against Escherichia coli, than the bud clove oil with inhibition zone of $11.10 \pm 0.153 \mathrm{~mm}$. Similar results were found against Staphylococcus aureus and Bacillus subtilis. For Staphylococcus aureus, inhibiton of leaf and stem oils are $14.57 \pm 0.513 \mathrm{~mm}$ and $13.47 \pm 0.451 \mathrm{~mm}$, respectively, while the inhibition zone of bud oils is $8.57 \pm 0.404 \mathrm{~mm}$. For Bacillus subtilis, inhibiton 
Table 2. Antibacterial activity of clove oil against Escherichia coli FNCC0091 and Salmonella typhimurium FNCC0157.

\begin{tabular}{ccccccccc}
\hline & \multicolumn{3}{c}{ Escherichia coli FNCC0091 } & \multicolumn{5}{c}{ Salmonella typhimurium FNCC0157 } \\
\cline { 2 - 9 } Clove oil & $1: 1(\mathrm{v} / \mathrm{v})$ & $1: 5(\mathrm{v} / \mathrm{v})$ & $1: 10(\mathrm{v} / \mathrm{v})$ & $1: 20(\mathrm{v} / \mathrm{v})$ & $1: 1(\mathrm{v} / \mathrm{v})$ & $1: 5(\mathrm{v} / \mathrm{v})$ & $1: 10(\mathrm{v} / \mathrm{v})$ & $1: 20(\mathrm{v} / \mathrm{v})$ \\
\cline { 2 - 9 } & & & \multicolumn{5}{c}{ Diameter of inhibition $(\mathrm{mm})^{1}$} \\
\hline Stem & $15.05 \pm 0.200^{\mathrm{a}}$ & $12.87 \pm 0.153^{\mathrm{a}}$ & $8.73 \pm 0.252^{\mathrm{a}}$ & $7.37 \pm 0.306^{\mathrm{a}}$ & $13.67 \pm 0.764^{\mathrm{a}}$ & $10.5 \pm 0.50^{\mathrm{a}}$ & $10.33 \pm 0.577^{\mathrm{a}}$ & $7.20 \pm 0.721^{\mathrm{a}}$ \\
Leaf & $13.5 \pm 0.322^{\mathrm{a}}$ & $11.90 \pm 0.954^{\mathrm{ab}}$ & $7.53 \pm 0.503^{\mathrm{b}}$ & $7.11 \pm 0.709^{\mathrm{a}}$ & $12.67 \pm 0.577^{\mathrm{ab}}$ & $10 \pm 0,978^{\mathrm{a}}$ & $8.83 \pm 0.763^{\mathrm{a}}$ & - \\
Bud & $11.10 \pm 0.153^{\mathrm{b}}$ & $10.17 \pm 0.289^{\mathrm{b}}$ & $7.60 \pm 0.529^{\mathrm{b}}$ & - & $11,70 \pm 0.577^{\mathrm{b}}$ & $9.67 \pm 0.577^{\mathrm{a}}$ & $8.67 \pm 0.578^{\mathrm{a}}$ & - \\
Ampicilin $^{2}$ & $8.17 \pm 0.379$ & - & - & - & $11.23 \pm 0.551$ & - & - & - \\
DMSO $^{2}$ & - & - & - & - & - & - & - & - \\
\hline
\end{tabular}

${ }^{1}$ Values are mean diameter of inhibitory zone $(\mathrm{mm}) \pm \mathrm{SD}$ of three replicates, followed by different letters in column are significantly different $(\mathrm{P}<0.05)$. The diameter of paperdisk $(6 \mathrm{~mm})$ is included. ${ }^{2}$ Ampicillin $(100 \mu \mathrm{g} / \mathrm{mL})$ used as positive control and DMSO used as negative control. ${ }^{3}$-: no antibacterial activity.

Table 3. Antibacterial activity of clove oil against Bacillus subtilis FNCC0060 and Staphylococcus aureus ATCC6538.

\begin{tabular}{|c|c|c|c|c|c|c|c|c|}
\hline \multirow{3}{*}{ Clove oil } & \multicolumn{4}{|c|}{ Bacillus subtilis FNCC0060 } & \multicolumn{4}{|c|}{ Staphylococcus aureus ATCC6538 } \\
\hline & $1: 1(\mathrm{v} / \mathrm{v})$ & $1: 5(\mathrm{v} / \mathrm{v})$ & $1: 10(\mathrm{v} / \mathrm{v})$ & $1: 20(\mathrm{v} / \mathrm{v})$ & $1: 1(\mathrm{v} / \mathrm{v})$ & $1: 5(\mathrm{v} / \mathrm{v})$ & $1: 10(\mathrm{v} / \mathrm{v})$ & $1: 20(\mathrm{v} / \mathrm{v})$ \\
\hline & \multicolumn{8}{|c|}{ Diameter of inhibition $(\mathrm{mm})^{1}$} \\
\hline Stem & $12.80 \pm 0.265^{\mathrm{a}}$ & $10.97 \pm 0.723^{\mathrm{a}}$ & $7.70 \pm 0.265^{\mathrm{a}}$ & - & $14.57 \pm 0.513^{\mathrm{a}}$ & $12.57 \pm 0.586^{\mathrm{a}}$ & $8.53 \pm 0.503^{\mathrm{a}}$ & $7.32 \pm 0.436^{\mathrm{a}}$ \\
\hline Leaf & $12.23 \pm 0.252^{\mathrm{a}}$ & $9.73 \pm 0.306^{\mathrm{b}}$ & $7.40 \pm 0.529^{\mathrm{a}}$ & - & $13.47 \pm 0.451^{\mathrm{a}}$ & $10.17 \pm 0.472^{\mathrm{b}}$ & $7.43 \pm 0.404^{\mathrm{b}}$ & - \\
\hline Bud & $10.5 \pm 0.500^{\mathrm{b}}$ & $8.27 \pm 0.643^{c}$ & $7.17 \pm 0.289^{\mathrm{a}}$ & - & $11.43 \pm 0.513^{\mathrm{b}}$ & $9.23 \pm 0.651^{\mathrm{b}}$ & $7.40 \pm 0.265^{\mathrm{b}}$ & - \\
\hline Ampicilin $^{2}$ & $27.57 \pm 0.586$ & - & - & - & $8.57 \pm 0.404$ & - & - & - \\
\hline $\mathrm{DMSO}^{2}$ & - & - & - & - & - & - & - & - \\
\hline
\end{tabular}

${ }^{1}$ Values are mean diameter of inhibitory zone $(\mathrm{mm}) \pm \mathrm{SD}$ of three replicates, followed by different letters in column are significantly different $(\mathrm{P}<0.05)$. The diameter of paper disk $(6 \mathrm{~mm})$ is included. ${ }^{2}$ Ampicillin $(50 \mu \mathrm{g} / \mathrm{mL})$ used as positive control and DMSO used as negative control. ${ }^{3}$-: no antibacterial activity.

Table 4. Minimum inhibitory concentration (MIC) and minimal bactericide concentration (MBC) of clove oil ${ }^{1}$.

\begin{tabular}{|c|c|c|c|c|c|c|c|c|}
\hline \multirow{3}{*}{ Essential oil } & \multicolumn{8}{|c|}{ Bacterial strain } \\
\hline & \multicolumn{2}{|c|}{ E. coli } & \multicolumn{2}{|c|}{ S. aureus } & \multicolumn{2}{|c|}{ B. subtilis } & \multicolumn{2}{|c|}{ S. typhimurium } \\
\hline & $\operatorname{MIC}(\mu \mathrm{L} / \mathrm{mL})$ & $\mathrm{MBC}(\mu \mathrm{L} / \mathrm{mL})$ & $\operatorname{MIC}(\mu \mathrm{L} / \mathrm{mL})$ & $\mathrm{MBC}(\mu \mathrm{L} / \mathrm{mL})$ & $\mathrm{MIC}(\mu \mathrm{L} / \mathrm{mL})$ & $\mathrm{MBC}(\mu \mathrm{L} / \mathrm{mL})$ & $\mathrm{MIC}(\mu \mathrm{L} / \mathrm{mL})$ & $\mathrm{MBC}(\mu \mathrm{L} / \mathrm{mL})$ \\
\hline Stem & $\geq 2.5$ & $\geq 10$ & $\geq 2.5$ & $\geq 10$ & $\geq 10$ & $\geq 50$ & $\geq 5$ & $\geq 10$ \\
\hline Leaf & $\geq 2.5$ & $\geq 10$ & $\geq 5$ & $\geq 25$ & $\geq 5$ & $\geq 25$ & $\geq 5$ & $\geq 10$ \\
\hline Bud & $\geq 5$ & $\geq 25$ & $\geq 5$ & $\geq 50$ & $\geq 10$ & $\geq 50$ & $\geq 10$ & $\geq 25$ \\
\hline
\end{tabular}

${ }^{1}$ Ampicilin was employed as positive control. The MBC to ampicilin was $100 \mu \mathrm{g} / \mathrm{mL}$ in all experiments.

of leaf and stem oils are $12.23 \pm 0.252 \mathrm{~mm}$ and $12.80 \pm 0.265 \mathrm{~mm}$, respectively, while the inhibition zone of bud oils $10.5 \pm 0.500 \mathrm{~mm}$. Different results were found against Salmonella typhimurium, where stem oil with inhibition zone of $13.67 \pm 0.764 \mathrm{~mm}$ is more active than bud oil with inhibition zone of $11.70 \pm$ $0.577 \mathrm{~mm}$, but is the same active as leaf oil with inhibition zone of $12.67 \pm 0.577$ $\mathrm{mm}$.

Minimum inhibitory concentration (MIC) and minimum bactericide concentration (MBC) for selected three oils ranged from $\geq 2.5$ to $\geq 10.0 \mu \mathrm{L} / \mathrm{mL}$ and $\geq 10$ 
to $\geq 50 \mu \mathrm{L} / \mathrm{mL}$ (Table 4). This study revealed MIC and MBC values for leaf oil range from 2.5 to $5.0 \mu \mathrm{L} / \mathrm{mL}$ and 10 to $25 \mu \mathrm{L} / \mathrm{mL}$, respectively. In addition, for stem oil, MIC and $\mathrm{MBC}$ values range from 2.5 to $10.0 \mu \mathrm{L} / \mathrm{mL}$ and 10 to 50 $\mu \mathrm{L} / \mathrm{mL}$, respectively. Finally, for bud oils MIC and MBC values range from 5 to $10.0 \mu \mathrm{L} / \mathrm{mL}$ and 25 to $50 \mu \mathrm{L} / \mathrm{mL}$, respectively.

The essential oil from the stem of $E$. caryophylata showed high antibacterial activity against E. coli and $S$. aureus $(\mathrm{MIC}=2.5 \mu \mathrm{L} / \mathrm{mL}$ and $\mathrm{MBC}=10 \mu \mathrm{L} / \mathrm{mL})$, and the leaf oil showed high antibacterial activity against $\mathrm{E}$. coli $(\mathrm{MIC}=2.5$ $\mu \mathrm{L} / \mathrm{mL}$ and $\mathrm{MBC}=10 \mu \mathrm{L} / \mathrm{mL}$ ).

In vitro studies in this work showed that the clove oils inhibited bacterial growth but their effectiveness varied and oil from stem of clove exhibited strong activity against the selected bacterial strains. This shows that antibacterial activity related to the components of eugenol contained in the cloves where the stem contains the highest compared to the leaf and bud. It has been previously reported [25] that oils induce antimicrobial activity because of the high concentration of eugenol and eucalyptol components. This result showed eugenol compound have aromatic ring and hydroxyl group as determining of antibacterial activity. Previous research showed that the antimicrobial activity of eugenol caused by the disruption of the bacterial cell membrane [26].

\section{Conclusion}

The chemical composition of essential oils from clove (Eugenia caryophylata) was investigated. Essential oil from bud, leaf and stem clove oil, was obtained from steam distillation method, and its chemical composition was determined by GC and GC-MS. Main components in the bud oil are eugenol (75.30\%), eugenyl acetate (20.93\%) and $\beta$-caryophyllene (3.00\%); in leaf oil, eugenol (82.97\%), $\beta$-caryophyllene (12.84\%), while in stem oil, eugenol (97.75\%). The Oils were tested for their in vitro antibacterial activities against Gram-positive bacteria (Staphylococcus aureus and Bacillus subtilis) and the Gram-negative bacteria (Escherichia coli and Salmonella typhimurium). The essential oil of buds, leaves and stems displayed marked broad spectrum antibacterial activity against Gram-positive and Gram-negative bacteria.

\section{Acknowledgements}

The authors are grateful to the Director General of Research and Community Service, Ministry of Research, Technology and Higher Education Indonesia for its financial support.

\section{References}

[1] Alma, M.H., Ertas, M., Nitz, S. and Kollmannsberger, H. (2007) Chemical Composition and Content of Essential Oil from the Bud of Cultivated Turkish Clove (Syzigium aromaticum L.). BioResources, 2, 265-269.

[2] Pundir, R.K., Jain, Pr. and Sharma, Ch. (2010) Antimicrobial Activity of Ethanolic Extracts of Syzigium aromaticum and Allium sativum against Food Associated Bac- 
teria and Fungi. Ethnobotanical Leaflets, 14, 344-360.

[3] Park, M.J., Gwak, K.S., Yang, I., Choi, W.S., Jo, H.J., Chang, J.W., Jeung, E.B. and Choi, I.G. (2007) Antifungal Activities of the Essential Oils in Syzigium aromaticum (L.) Merr. Et Perry and Leptospermum patersoii Bailey and Their Constituents against Various Dermatophytes. Journal of Microbiology, 45, 460-465.

[4] Humini, K.N., Hamdane, R., Boutoutaou, R., Kihal, M. and Henni, J.E. (2014) Antifungal Activity of Clove (Syzigium aromaticum L.) Essential Oil against Phytopathogenic Fungi of Tomato (Solanum lycopersicum L.) in Algeria. Journal of Experimental Biology and Agriculture Sciences, 2, 447-454.

[5] Yazdanpanah, L. and Mohamadi, N. (2014) Antifungal Activity of the Clove Essential oil Syzigium aromaticum on Paecilomyces variotii Agent of Pistachio Dieback. Journal of Biodiversity and Environmental Sciences, 4, 42-45.

[6] Jirovetz, L., Buchbauer, G., Stoilova, I., Stoyanova, A. and Schmidt, E. (2006) Chemical Composition and Antioxidant Properties of Clove Leaf Essential Oil. Journal of Agricultural and Food Chemistry, 54, 6303-6307. https://doi.org/10.1021/jf060608c

[7] Nassar, M.I., Gaara, A.H., El-Ghorab, A.H., Farrag, A.R.H., Shen, H., Huq, E. and Mabry, T.J. (2007) Chemical Constituents of Clove (Syzigium aromaticum), Fam. Myrtaceae and Their Antioxidant Activity. Revista Latinoamericana de Química, 35, 47-57.

[8] Abozid, M.M. and El-Sayed, S.M. (2013) Antioxidant and Protective Effect of Clove Extracts and Clove Essential Oil on Hydrogen Peroxide Treated Rats. International Journal of Chem Tech Research, 5, 1477-1485.

[9] Saeed, M., Nadeem, M., Khan, M.R., Shabbir, M.A., Shehzad, A. and Amir, A.M. (2013) Antimicrobial Activity of Syzigium aromaticum Extracts against Food Spoilage Bacteria. African Journal of Microbiology Research, 7, 4848-4856.

[10] Cortes-Rojas, D.F., Ferandes de Souza, C.R. and Pereira Olivera, W. (2014) Clove (Syzigium aromaticum): A Precious Spice. Asian Pacific Journal of Tropical Biomedicine, 4, 90-96. https://doi.org/10.1016/S2221-1691(14)60215-X

[11] Chaieb, K., Hajlaoui, H., Zmantar, T., Kahla-Nakbi, A.B., Rouambhia, M., Mahdouani, K. and Bakhroul, A. (2007) The Chemical Composition and Biological Activity of Clove Essential Oil, Eugenia caryophyllata (Syzigium aromaticum L. Myrtaceae): A Short Review. Phytotherapy Research, 21, 501-506.

https://doi.org/10.1002/ptr.2124

[12] Ozturk, A. and Ozbek, H. (2005) The Anti-Inflammatory Activity of Eugenia caryophyllata Essential Oil: An Animal Model of Anti-Inflammatory Activity. European Journal of General Medicine, 2, 159-163. https://doi.org/10.29333/ejgm/82334

[13] Kamatou, G.P., Vermaak, I. and Viljoen, A.M. (2012) Eugenol-From the Remote Maluku Islands to the International Market Place: A Review of a Remarkable and Versatile Molecule. Molecules, 17, 6953-6981. https://doi.org/10.3390/molecules17066953

[14] Wei, Ch., Meen, W.H., Hsi, Ch.W., Yin, Y.Ch., Yao, Ch.H. and Je, Ch. (2011) The Analysis of Eugenol from the Essential Oil of Eugenia caryophyllata by HPLC and against the Proliferation of Cervical Cancer Cells. Journal of Medicinal Plants Research, 5, 1121-1127.

[15] Vidhya, N. and Devaray, S.N. (2011) Induction of Apoptosis by Eugenol in Human Breast Cancer Cells. Indian Journal of Experimental Biology, 49, 871-878.

[16] Sohilait, H.J., Sastrohamidjojo, H., Sabirin, M. and Gossert, J.S. (2005) Synthesis of Analog L- $\alpha$-Methyl DOPA from Eugenol. Indonesian Journal of Chemistry, 5, 
198-202.

[17] Bhuiyan, Md.N.I., Begum, J., Nandi, N.Ch. and Akter, F. (2010) Constituents of the Essential Oil from Leaves and Buds of Clove (Syzigium aromaticum, L. Alston). African Journal of Plant Science, 4, 451-454.

[18] Srivastava, A.K., Srivastava, S.K. and Syamsudar, K.V. (2005) Bud and Leaf Essential Oil Composition of Syzygium aromaticum from India and Madagascar. Flavour and Fragrance Journal, 20, 51-53. https://doi.org/10.1002/ffj.1364

[19] Razafimamonjison, G., Jahiel, M., Duclos, Th., Ramanoelia, P., Fawbush, F. and Danthu, P. (2014) Bud, Leaf and Stem Essential Oil Composition of Syzigium aromaticum from Madagascar, Indonesia and Zanzibar. International Journal of Basic and Applied Sciences, 3, 224-233.

[20] Gupta, M., Singh, D., Gularia, P. and Gupta, S. (2015) GCMS Analysis and Identifications of Chemical Constituents of Syzigium aromaticum, Brassica compestris and Cow Ghee. Journal of Chemical and Pharmaceutical Research, 7, 568-572.

[21] Sohilait, H.J. (2015) Chemical Composition of the Essential Oils in Eugenia caryophyllata, Thunb from Amboina Island. Science Journal of Chemistry, 3, 95-99.

[22] Lai, H.Y., Yau, Y.Y. and Kim, K.H. (2010) Blechnumorientale Linn-A Fern with Potential as Antioxidant, Anticancer and Antibacterial Agent. BMC Complementary and Alternative Medicine, 10, 1-8.

[23] Mith, H., Dure, R., Delcenserie, V., Zhiri, A., Daube, G. and Clinquart, A. (2014) Antimicrobial Activities of Essential Oils and Their Components against Food-Borne Pathogens and Food Spoilage Bacteria. Food Science \& Nutrition, 2, 403-416. https://doi.org/10.1002/fsn3.116

[24] Valenta, K., Nevo, O., Martel, C. and Champan, C.A. (2017) Plant Attractant; Integrating in Sights from Pollination and Seed Dipersal Ecology. Evolutionary Ecology, 31, 249-267.

[25] Kumar, U.K., Bhandari, A. and Kumar, Y. (2010) Phytochemical Investigation and Comparison of Antimicrobial Screening of Clove and Cardamom. International Journal of Pharmaceutical Sciences and Research, 1, 138-147.

[26] Devi, K.P., Nisha, S.A., Sakthivel, R. and Pandian, K. (2010) Eugenol (An Essential Oil of Clove) Acts as an Antibacterial Agent against Salmonella typi by Disrupting the Cellular Membrane. Journal of Ethnopharmacology, 130, 107-115. https://doi.org/10.1016/j.jep.2010.04.025 